\title{
Development of in vitro Propagation Protocol for Newly Developed Mutants of Carnation (Dianthus caryophyllus L.)
}

\author{
Rishu Doad, Puja Sharma*, S.R. Dhiman and Priyanka Sharma \\ Department of Floriculture and Landscape Architecture \\ Dr YSP University of Horticulture and Forestry Nauni, Solan 173230, India \\ *Corresponding author
}

\section{A B S T R A C T}

\section{Keywords}

Carnation, in vitro, regeneration, Shoot tip, Nodal segment, Establishment, Multiplication, rooting

\section{Article Info}

Accepted:

04 March 2019

Available Online:

10 April 2019
A study on the development of in vitro propagation protocol for newly developed mutants of Carnation (Dianthus caryophyllus L.)" was carried out during 2017-2018. Results reveal that all the mutants responded well to the in vitro propagation, however 'UHFS Car-4' exhibited best propagation potential. Calcium Hypochlorite (5\%) treatment for $20 \mathrm{~min}$. is suggested for surface sterilization of explants as it gives $100 \%$ uncontaminated growing cultures. For initial culture establishment, MS medium supplemented with $2.0 \mathrm{mgl}^{-1} \mathrm{BA}$ proved to be most effective resulting in earliest establishment. Shoot tips were found better than nodal segment explants for multiplication of carnation. High quality shoots along with best multiplication rate could be obtained in medium containing $\mathrm{MS}+3.0 \mathrm{mgl}^{-1} \mathrm{BA}+0.1$ $\mathrm{mgl}^{-1}$ NAA. Same medium resulted in maximum shoot proliferation (5.13) in 'UHFS Car1 ' and 'UHFS Car-18'. In case of 'UHFS Car-4' maximum proliferation (5.36) was noted in $\mathrm{MS}+\mathrm{BA} 2.5 \mathrm{mgl}^{-1}+\mathrm{NAA} 0.1 \mathrm{mgl}^{-1}$ whereas in 'UHFS Car-33'same effect was obtained (5.26) in MS + BA $2.5 \mathrm{mgl}^{-1}+\mathrm{NAA} 0.1 \mathrm{mgl}^{-1}+\mathrm{GA}_{3} 1.0 \mathrm{mgl}^{-1}$. Half strength MS medium containing $2.0 \mathrm{mgl}^{-1} \mathrm{NAA}$ and $0.1 \%$ activated charcoal was found to be the best for in vitro rooting of multiplied shoots. A medium containing sand, cocopeat and vermicompost $(1: 1: 1, \mathrm{v} / \mathrm{v})$ was found best for hardening of in vitro regenerated shoots resulting in $79.16 \%$ survival and maximum growth under field conditions.

\section{Introduction}

Carnation (Dianthus caryophyllus L.) is an important commercial cut flower crop. High quality carnation are produced in countries like Italy, Spain, Colombia, Kenya, Israel, SriLanka, Canary Islands, France, Holland, Germany and U.S.A. (Misra et al., 2006). India also has a huge potential of producing carnations and is being cultivated in small pockets in Nasik and Pune in Maharashtra, Bangalore, Coimbatore, Delhi, Uttar Pradesh, Punjab, West Bengal, Kashmir and Himachal Pradesh. Presently, all the area covered under carnation cultivation is occupied by exotic varieties. Due to high cost of planting material of these varieties, large scale cultivation is very limited. Mutation breeding work carried out in the department has resulted in development of flower colour 
mutants. The newly developed carnation genotypes offer a substitute for expensive planting material of exotic varieties which are under cultivation in different parts of the country.

Further, plant tissue culture techniques can be exploited for faster multiplication of the elite indigenous planting material. The commercial technology is primarily based on micropropagation in which rapid proliferation is achieved from tiny stem cuttings, axillary buds etc. (Ahloowalia et al., 2002).

The present study, was therefore conducted to develop an in vitro propagation protocol for production of healthy disease free indigenous planting material of newly developed mutants available to the growers at cheap and affordable prices.

\section{Materials and Methods}

The present investigations were carried out in the Plant Tissue Culture Laboratory and Experimental Farm of department of Floriculture and Landscape Architecture, Dr YSParmar University of Horticulture and Forestry, Nauni, Solan (HP) during 2017-18. For carrying out the present investigations, newly developed carnation mutants namely 'UHFS Car-1', 'UHFS Car-4', 'UHFS Car18' and 'UHFS Car-33' were selected. In vitro studies were conducted by using Murashige and Skoog (1962) nutrient medium. After adding the required amount of growth regulators, MS medium was supplemented with $3 \%$ sucrose and $0.65 \%$ agar-agar. The culture vessels carrying desired medium was sterilized in an autoclave at $121^{\circ} \mathrm{C}$ and $1.05 \mathrm{~kg} / \mathrm{cm}^{2}$ pressure $(15 \mathrm{psi})$ for 20 minutes (Dodds and Roberts, 1982). Two explants; shoot tips and nodal segments were used for initial establishment of cultures and treated with Calcium Hypochlorite as surface sterilization treatment for varying durations under laminar air flow cabinet followed by washing and inoculation. All the cultures were kept in the culture trolleys of culture room maintained at a temperature of $25 \pm 2{ }^{\circ} \mathrm{C}$ under artificial light (16 hours light and 8 hours dark period daily) for incubation. Different experiments on surface sterilization of explants, culture establishment, shoot multiplication, rooting and hardening were carried out and various parameters were recorded. The data was subjected to analysis using CRD (factorial) (Sheoran et al., 1998).

\section{Results and Discussion}

Data presented in Table 1 shows that all the mutants behaved similarly with respect to per cent uncontaminated growing cultures and $100 \%$ uncontaminated growing cultures were obtained when the explants were treated with $5 \%$ Calcium Hypochlorite $\mathrm{Ca}(\mathrm{OCl})_{2}$ for 20 minutes irrespective of genotype and source of explant.

Efficacy of Calcium Hypochlorite $\mathrm{Ca}(\mathrm{OCl})_{2}$ for surface sterilization of explants of carnation has been reported earlier also. Sangwan et al., (1987) successfully used 5\% Calcium Hypochlorite $\mathrm{Ca}(\mathrm{OCl})_{2}$ for surface sterilization of carnation shoots for 10 minutes, while Roest and Bokelmann (1981) surface sterilized flower pedicels of carnation for 20 minutes with same sterilant. Gautam (2015) also advocated the use of 5\% Calcium Hypochlorite $\mathrm{Ca}(\mathrm{OCl})_{2}$ for 20 , and 25 minutes for surface sterilization of apical and nodal segments of carnation cv. 'Parendillo' and 'Yellow Star', respectively.

A perusal of data in the Table 2 reveals that earliest culture establishment was observed in 'UHFS Car-4' (21.81 days). On the other hand, cultures of 'UHFS Car-1' took maximum time for establishment (23.99 days).In case of explants, nodal segments of carnation (22.79 days) showed earlier 
establishment in vitro than shoot tips (23.43 days). All the media under testing containing different levels of BA resulted in earlier culture establishment over control. However, earliest culture establishment (16.46 days) was recorded in $T_{5}$ i.e. basal MS medium supplemented with $2.0 \mathrm{mgl}^{-1} \mathrm{BA}$, irrespective of genotype.

It is also evident from Table 2 that the interaction between mutants and explants and showed a significant effect on culture establishment. Carnation mutant 'UHFS Car4' took minimum days for culture establishment (21.51 days) when nodal segments were used as explant and found to be at par with shoot tip cultures of 'UHFS Car-4' (22.11 days). In contrast, 'UHFS Car1 ' took maximum days for establishment (24.34 days) when shoot tips were used as explant. Similar results were, however obtained in 'UHFS Car-33' (23.66 days) and 'UHFS Car-1' (23.63 days) when shoot tip and nodal segments were used as explants, respectively.

Data on shoot multiplication in vitro is presented in Table 3 which shows that 'UHFS Car-4' produced maximum number of shoots (4.27) one month after culturing which was found to be at par with shoot multiplication in 'UHFS Car-18' (4.22). In contrast, least multiplication was noted in 'UHFS Car-33' (4.05). Further, it was also observed that shoots regenerated from shoot tip explants (4.29) proved better in comparison to nodal segments (4.05) for inducing multiple shoot formation under in vitro conditions. Among media combinations, MS medium containing $3.0 \mathrm{mgl}^{-1} \mathrm{BA}+0.1 \mathrm{mgl}^{-1} \mathrm{NAA}\left(\mathrm{T}_{6}\right)$ was found to be the most effective treatment for multiple shoot formation producing 5.12 shoots. In contrast, minimum number of shoots (2.71) were observed in MS medium containing 2.0 $\mathrm{mg}^{-1} \mathrm{BA}\left(\mathrm{T}_{1}\right)$. Further, interaction between the explants and treatments show that maximum shoot multiplication (5.21) was obtained when the shoots grown from shoot tip explants were cultured on $\mathrm{T}_{6}$ i.e. $\mathrm{MS}+3.0$ $\mathrm{mgl}^{-1} \mathrm{BA}+0.1 \mathrm{mgl}^{-1} \mathrm{NAA}$. Similar results were, however, found when shoots obtained from shoot tip explants were (5.17) cultured on $\mathrm{MS}+2.5 \mathrm{mgl}^{-1} \mathrm{BA}+0.1 \mathrm{mgl}^{-1} \mathrm{NAA}+1.0$ $\mathrm{mgl}^{-1} \mathrm{GA}_{3}\left(\mathrm{~T}_{8}\right)$.

The interaction between mutants, growth regulators and explants shows that maximum multiplication was recorded from shoot tip raised shoots of 'UHFS Car-18' (5.43) when placed on $\mathrm{T}_{6}$ i.e. MS medium containing 3.0 $\mathrm{mgl}^{-1} \mathrm{BA}+0.1 \mathrm{mgl}^{-1} \mathrm{NAA}$. Similar results were, however, obtained from shoot tips of 'UHFS Car-4' (5.36) cultured on MS + 2.5 $\mathrm{mgl}^{-1} \mathrm{BA}+0.1 \mathrm{mgl}^{-1} \mathrm{NAA}\left(\mathrm{T}_{5}\right)$ and shoot tips (5.26) of 'UHFS Car-4' and 'UHFS Car-33' cultured on MS medium added with $2.5 \mathrm{mgl}^{-1}$ $\mathrm{BA}+0.1 \mathrm{mgl}^{-1} \mathrm{NAA}+1.0 \mathrm{mgl}^{-1} \mathrm{GA}_{3}\left(\mathrm{~T}_{8}\right)$.

In the present study, better shoot multiplication was noted in 'UHFS Car-4' over other mutants. It could be attributed to genotypic differences amongst them. These findings are in line with the reports of Sharma et al, 2016, who showed differential behaviour of different carnation genotypes during in vitro multiplication. Simultaneously maximum number of shoots were obtained in the shoot tip regenerated cultures of mutant 'UHFS Car-4' when cultured on MS medium supplemented with $3.0 \mathrm{mgl}^{-1} \mathrm{BA}$ and $0.1 \mathrm{mgl}^{-1}$ NAA. A positive influence of auxin and cytokinin combination on plantlet regeneration in vitro is a well established fact (Skoog and Miller, 1957) and was confirmed by several researchers (Pennazio, 1975 and Hempel, 1979).

Usually, hormonal combinations with high concentrations of cytokinins $(2-10 \mu \mathrm{M})$ and low concentrations of auxins $(0.1-0.5 \mu \mathrm{M})$ are effective for multiple shoot formation from shoot apex. Similar results were reported by 
Iantcheva et al., (2005) who studied that optimum regeneration in carnation was noticed in medium supplemented with $0.9 \mathrm{mgl}^{-1}$ BAP and $0.9 \mathrm{mgl}^{-1}$ NAA. Choudhary (1991) also concluded that highest shoot number (8.7) was obtained in MS + BA 0.25 $\mu \mathrm{M}+$ NAA $0.01 \mu \mathrm{M}$ in carnation. According to Pareek et al., 2004, best shoot proliferation could be obtained in Dianthus caryophyllus, Dianthus chinensis and Dianthus barbatus when shoot tips or nodal segments were cultured on a medium containing a combination of BA and NAA i.e. $\mathrm{MS}+1$ $\mathrm{mgl}^{-1} \mathrm{BA}+0.5 \mathrm{mgl}^{-1} \mathrm{NAA}$. Multiple shoot formation in carnation in $\mathrm{MS}$ medium containing $1.5 \mathrm{mgl}^{-1} \mathrm{BAP}$ and $0.5 \mathrm{mgl}^{-1} \mathrm{NAA}$ has also been reported by Kansagra et al., 2008 from nodal explants. A high frequency plant regeneration system from shoot tips and nodal explants of carnation was reported on $\mathrm{MS}+0.5 \mathrm{mgl}^{-1} \mathrm{BAP}+0.1 \mathrm{mgl}^{-1} \mathrm{NAA}$ (Hassan et al., 2011). Similar reports by Kharrazi et al., (2011), Qaoud (2013) Markovic et al.,(2013) and Varshney et al., (2013) showed high plant regeneration in carnation with different concentrations and combinations of $\mathrm{BA}$ and NAA in MS medium.

The data in Table 4 revealed that the mutants under study showed significant differences amongst them with respect to shoot length observed during multiplication. Longest shoots $(4.28 \mathrm{~cm})$ were recorded in mutant 'UHFS Car-4' which was statistically at par with shoot length obtained in 'UHFS Car-33' $(4.24 \mathrm{~cm})$. On the other hand, minimum shoot length was noted for 'UHFS Car-1' $(3.97 \mathrm{~cm})$ which was found to be at par with 'UHFS Car-18' (4.03 cm). Data also depicts that longer shoots were obtained from shoots regenerated from nodal explants $(4.38 \mathrm{~cm})$ as compared to shoot tips $(3.89 \mathrm{~cm})$. It is also clear from the data that different media combinations have significantly affected shoot length in multiplication phase.
Maximum length of shoots $(5.88 \mathrm{~cm})$ was found in $\mathrm{T}_{7}$ i.e. $\mathrm{MS}$ medium added with 2.0 $\mathrm{mgl}^{-1} \mathrm{BA}+0.1 \mathrm{mgl}^{-1} \mathrm{NAA}+1.0 \mathrm{mgl}^{-1} \mathrm{GA}_{3}$. In contrast, minimum shoot length $(2.69 \mathrm{~cm})$ was noted in MS medium containing $2.0 \mathrm{mgl}^{-}$ ${ }^{1} \mathrm{BA}\left(\mathrm{T}_{1}\right)$. A significant increase in the length of shoots was, however observed with addition of $\mathrm{GA}_{3}$ in the medium. Sharma et al (2016) also reported that a considerable increase in shoot length of different carnation cultivars under in vitro was obtained by addition of $\mathrm{GA}_{3}$ in MS medium.

Interaction between mutants and growth regulators shows that a medium containing $2.0 \mathrm{mgl}^{-1} \mathrm{BA}+0.1 \mathrm{mgl}^{-1} \mathrm{NAA}+1.0 \mathrm{mgl}^{-1}$ $\mathrm{GA}_{3}\left(\mathrm{~T}_{7}\right)$ was found to be the most effective for increasing the length of shoots. Maximum shoot length $(6.18 \mathrm{~cm})$ was recorded in mutant 'UHFS Car-33' cultured on $\mathrm{T}_{7}$. Similar results were obtained in 'UHFS Car1' $(6.01 \mathrm{~cm})$ grown in same medium and 'UHFS Car-33' $(6.03 \mathrm{~cm})$ cultured on $\mathrm{T}_{9}$ i.e. $\mathrm{MS}+3.0 \mathrm{mgl}^{-1} \mathrm{BA}+0.1 \mathrm{mgl}^{-1} \mathrm{NAA}+1.0$ $\mathrm{mgl}^{-1} \mathrm{GA}_{3}$. In contrast, minimum shoot length was found in mutant 'UHFS Car-4' $(2.60 \mathrm{~cm})$ in MS medium added with $2.0 \mathrm{mgl}^{-1} \mathrm{BA}\left(\mathrm{T}_{1}\right)$. It was, however, found to be at par with shoot length obtained in the mutant 'UHFS Car-1' $(2.63 \mathrm{~cm})$, 'UHFS Car-18' $(2.73 \mathrm{~cm})$ and 'UHFS Car-33' (2.80 cm) cultured on same medium and in 'UHFS Car-1' $(2.73 \mathrm{~cm})$, 'UHFS Car-4' (2.83 cm) and 'UHFS Car-18' $(2.83 \mathrm{~cm})$ cultured on $2.5 \mathrm{mgl}^{-1} \mathrm{BA}\left(\mathrm{T}_{2}\right)$.

Data on interaction between explants and growth regulators revealed that maximum shoot length $(6.11 \mathrm{~cm})$ was obtained when nodal shoots were cultured on $\mathrm{T}_{7}$ i.e. MS medium containing $2.0 \mathrm{mgl}^{-1} \mathrm{BA}+0.1 \mathrm{mgl}^{-1}$ $\mathrm{NAA}+1.0 \mathrm{mgl}^{-1} \mathrm{GA}_{3}$. Minimum length of shoots $(2.61 \mathrm{~cm})$, was however, found when the shoots obtained from shoot tip explants were cultured on MS medium containing 2.0 $\mathrm{mgl}^{-1}$ BA $\left(\mathrm{T}_{1}\right)$. It is evident from the interaction data between mutants and explants 
that the longest shoots $(4.63 \mathrm{~cm})$ were obtained from nodal segments in mutant 'UHFS Car-4' while minimum length of shoots $(3.71 \mathrm{~cm})$ was noted in shoots obtained from shoot tips of mutant 'UHFS Car-1'.

The interaction data between mutants, growth regulators and explants shows that length of shoots was found maximum $(6.23 \mathrm{~cm})$ in the nodal segment raised shoots of mutant 'UHFS Car-33' when cultured on $\mathrm{T}_{7}$ i.e. $\mathrm{MS}+2.0$ $\mathrm{mgl}^{-1} \mathrm{BA}+0.1 \mathrm{mgl}^{-1} \mathrm{NAA}+1.0 \mathrm{mgl}^{-1} \mathrm{GA}_{3}$ which was found to be at par with shoots regenerated from shoot tips $(5.90 \mathrm{~cm})$ and nodal segments $(6.13 \mathrm{~cm})$ of mutant 'UHFS Car-1', nodal segments $(6.10 \mathrm{~cm})$ of mutant
'UHFS Car-4' and 'UHFS Car-18' (6.00 cm) and shoot tips $(6.13 \mathrm{~cm})$ of mutant 'UHFS Car-33' when cultured on same medium, shoots regenerated from nodal segments $(6.10$ $\mathrm{cm})$ of mutant 'UHFS Car-4' cultured on MS medium containing $2.5 \mathrm{mgl}^{-1} \mathrm{BA}+0.1 \mathrm{mgl}^{-1}$ $\mathrm{NAA}+1.0 \mathrm{mgl}^{-1} \mathrm{GA}_{3}\left(\mathrm{~T}_{8}\right)$ and nodal segments $(6.20 \mathrm{~cm})$ of mutant 'UHFS Car-33' cultured on $\mathrm{MS}+3.0 \mathrm{mgl}^{-1} \mathrm{BA}+0.1 \mathrm{mgl}^{-1}$ $\mathrm{NAA}+1.0 \mathrm{mgl}^{-1} \mathrm{GA}_{3}\left(\mathrm{~T}_{9}\right)$. In contrast, minimum shoot length $(2.53 \mathrm{~cm})$ was noted in the shoots regenerated from shoot tips in mutant 'UHFS Car-1' when cultured on medium containing $2.0 \mathrm{mgl}^{-1} \mathrm{BA}\left(\mathrm{T}_{1}\right)$.

Table.1 Effect of surface sterilization treatments and explants on percent uncontaminated growing cultures in carnation

\begin{tabular}{|c|c|c|c|c|c|c|c|}
\hline \multirow{2}{*}{$\begin{array}{l}\text { Treatments } \\
\mathrm{Ca}\left(\mathrm{OCl}_{2}\right) 5 \% \\
(\text { min. })\end{array}$} & \multicolumn{4}{|c|}{ Mutants of carnation } & \multirow[t]{2}{*}{ Mean } & \multicolumn{2}{|c|}{ Explants } \\
\hline & $\begin{array}{c}\text { UHFS Car- } \\
1\end{array}$ & $\begin{array}{l}\text { UHFS } \\
\text { Car-4 }\end{array}$ & $\begin{array}{c}\text { UHFS Car- } \\
18\end{array}$ & $\begin{array}{l}\text { UHFS } \\
\text { Car-33 }\end{array}$ & & Shoot tip & Nodal \\
\hline$T_{1}: 5$ & $\begin{array}{l}75.00 \\
(8.66)^{*}\end{array}$ & $\begin{array}{l}83.33 \\
(9.13)\end{array}$ & $\begin{array}{l}75.00 \\
(8.66)\end{array}$ & $\begin{array}{l}80.00 \\
(8.94)\end{array}$ & $\begin{array}{l}78.33 \\
(8.85)\end{array}$ & $\begin{array}{l}75.83 \\
(8.71)\end{array}$ & $\begin{array}{l}80.83 \\
(8.99)\end{array}$ \\
\hline$T_{2}: 10$ & $\begin{array}{l}83.33 \\
(9.13)\end{array}$ & $\begin{array}{l}88.33 \\
(9.40)\end{array}$ & $\begin{array}{l}81.66 \\
(9.04)\end{array}$ & $\begin{array}{l}80.33 \\
(8.96)\end{array}$ & $\begin{array}{l}84.16 \\
(9.17)\end{array}$ & $\begin{array}{l}80.83 \\
(8.99)\end{array}$ & $\begin{array}{l}87.50 \\
(9.35)\end{array}$ \\
\hline$T_{3}: 15$ & $\begin{array}{l}100.00 \\
(10.00)\end{array}$ & $\begin{array}{l}100.00 \\
(10.00)\end{array}$ & $\begin{array}{l}98.33 \\
(9.92)\end{array}$ & $\begin{array}{l}100.00 \\
(10.00)\end{array}$ & $\begin{array}{l}99.58 \\
(9.92)\end{array}$ & $\begin{array}{l}99.16 \\
(9.96)\end{array}$ & $\begin{array}{l}100.00 \\
(10.00)\end{array}$ \\
\hline$T_{4}: 20$ & $\begin{array}{l}100.00 \\
(10.00)\end{array}$ & $\begin{array}{l}100.00 \\
(10.00)\end{array}$ & $\begin{array}{l}100.00 \\
(10.00)\end{array}$ & $\begin{array}{l}100.00 \\
(10.00)\end{array}$ & $\begin{array}{l}100.00 \\
(10.00)\end{array}$ & $\begin{array}{l}100.00 \\
(10.00)\end{array}$ & $\begin{array}{l}100.00 \\
(10.00)\end{array}$ \\
\hline$T_{5}: 25$ & $\begin{array}{l}96.66 \\
(9.83)\end{array}$ & $\begin{array}{l}100.00 \\
(10.00)\end{array}$ & $\begin{array}{l}98.33 \\
(9.92)\end{array}$ & $\begin{array}{l}100.00 \\
(10.0)\end{array}$ & $\begin{array}{l}98.75 \\
(9.94)\end{array}$ & $\begin{array}{l}98.33 \\
(9.92)\end{array}$ & $\begin{array}{l}99.16 \\
(9.96)\end{array}$ \\
\hline$T_{6}: 30$ & $\begin{array}{l}95.00 \\
(9.75)\end{array}$ & $\begin{array}{l}91.66 \\
(9.57)\end{array}$ & $\begin{array}{l}95.00 \\
(9.75)\end{array}$ & $\begin{array}{l}95.00 \\
(9.75)\end{array}$ & $\begin{array}{l}94.16 \\
(9.70)\end{array}$ & $\begin{array}{l}95.00 \\
(9.75)\end{array}$ & $\begin{array}{l}93.33 \\
(9.66)\end{array}$ \\
\hline $\mathbf{T}_{7}: 35$ & $\begin{array}{l}85.00 \\
(9.22)\end{array}$ & $\begin{array}{l}85.00 \\
(9.22)\end{array}$ & $\begin{array}{l}85.00 \\
(9.22)\end{array}$ & $\begin{array}{l}85.00 \\
(9.22)\end{array}$ & $\begin{array}{l}85.00 \\
(9.22)\end{array}$ & $\begin{array}{l}83.33 \\
(9.13)\end{array}$ & $\begin{array}{l}86.66 \\
(9.31)\end{array}$ \\
\hline Mean & $\begin{array}{l}90.71 \\
(9.52)\end{array}$ & $\begin{array}{l}92.61 \\
(9.62)\end{array}$ & $\begin{array}{l}90.47 \\
(9.51)\end{array}$ & $\begin{array}{l}91.90 \\
(9.59)\end{array}$ & - & $\begin{array}{l}90.35 \\
(9.51)\end{array}$ & $\begin{array}{l}92.50 \\
(9.62)\end{array}$ \\
\hline $\begin{array}{l}\text { *values in parent } \\
\text { CD } \\
\text { CD.05: }\end{array}$ & $\begin{array}{l}\text { are square } r \\
\text { ants } \\
\text { ants } \\
\text { tments } \\
\text { ants } \times \text { Treatm } \\
\text { ants } \times \text { Treatn }\end{array}$ & transfor & d values. & & & & \\
\hline
\end{tabular}


Table.2 Effect of Benzyl Adenine (BA) concentrations in MS medium, explants and their interactions on days taken for culture establishment in carnation mutants

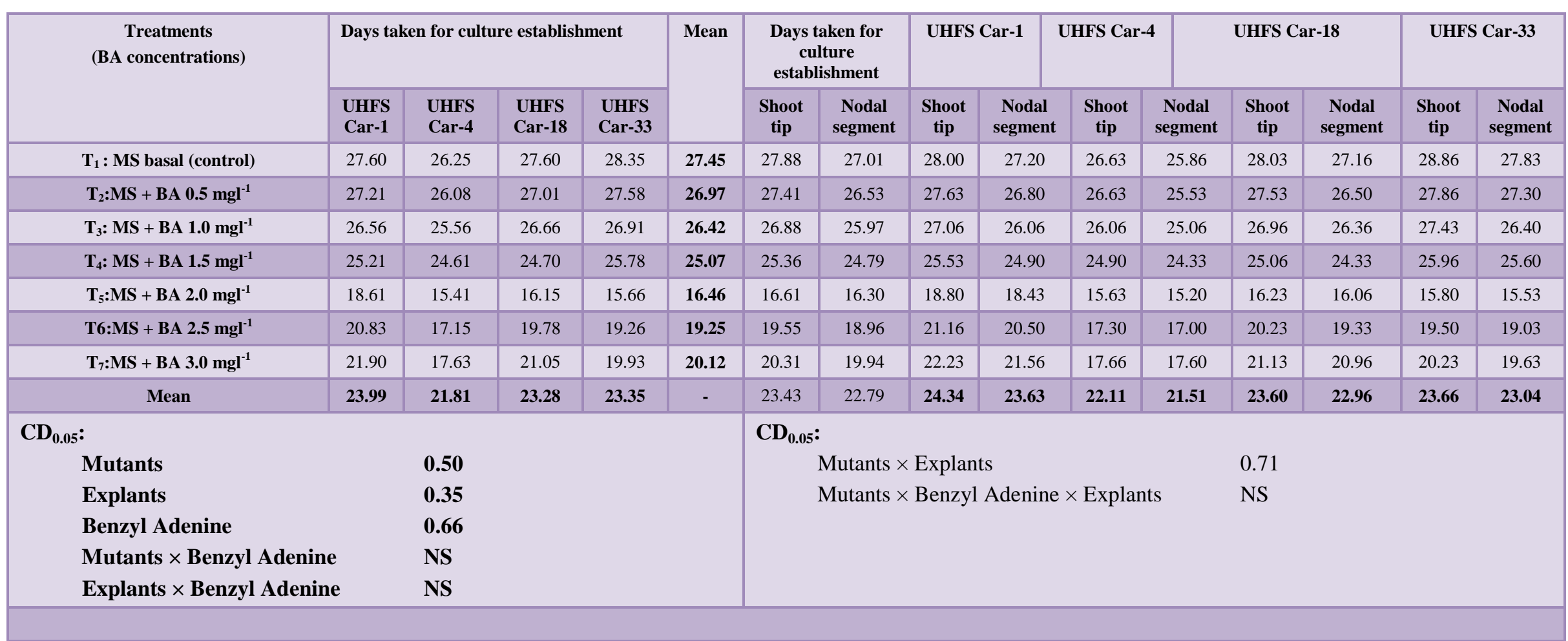


Table.3 Effect of multiplication media and explants and their interactions on shoot multiplication in carnation mutants

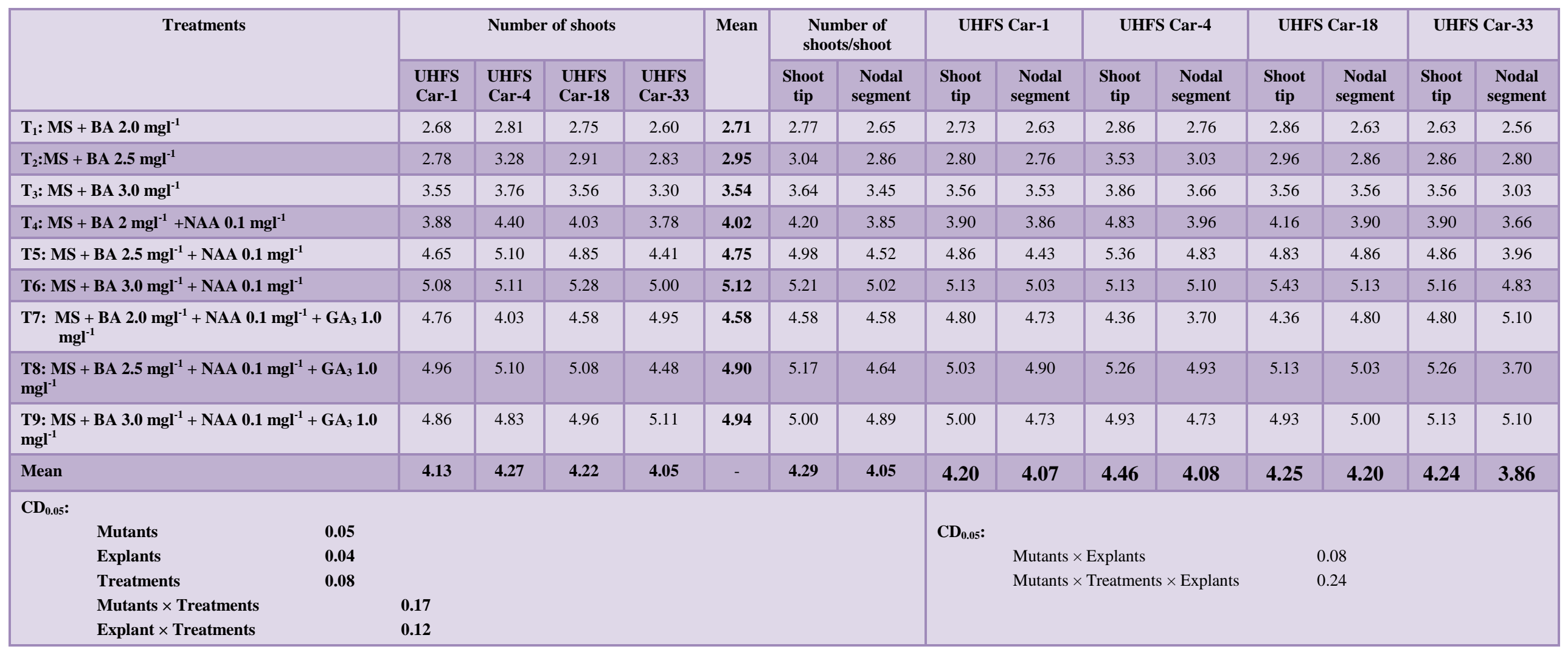




\section{Int.J.Curr.Microbiol.App.Sci (2019) 8(4): 183-195}

Table.4 Effect of multiplication media, explants and their interactions on length of shoots $(\mathrm{cm})$ in carnation

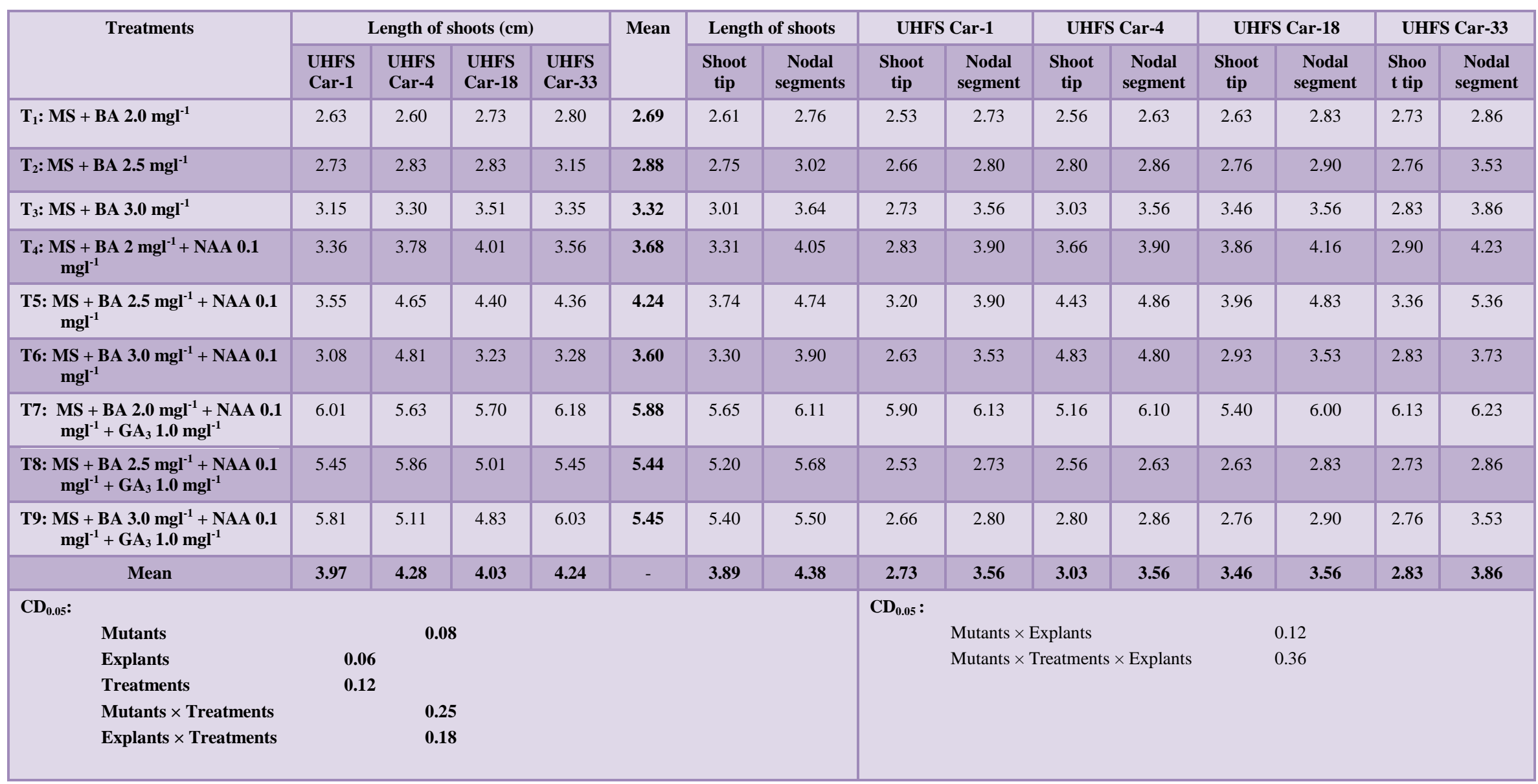


Fig.1 Effect of MS medium supplements on percent rooting of in vitro regenerated shoots of carnation mutants

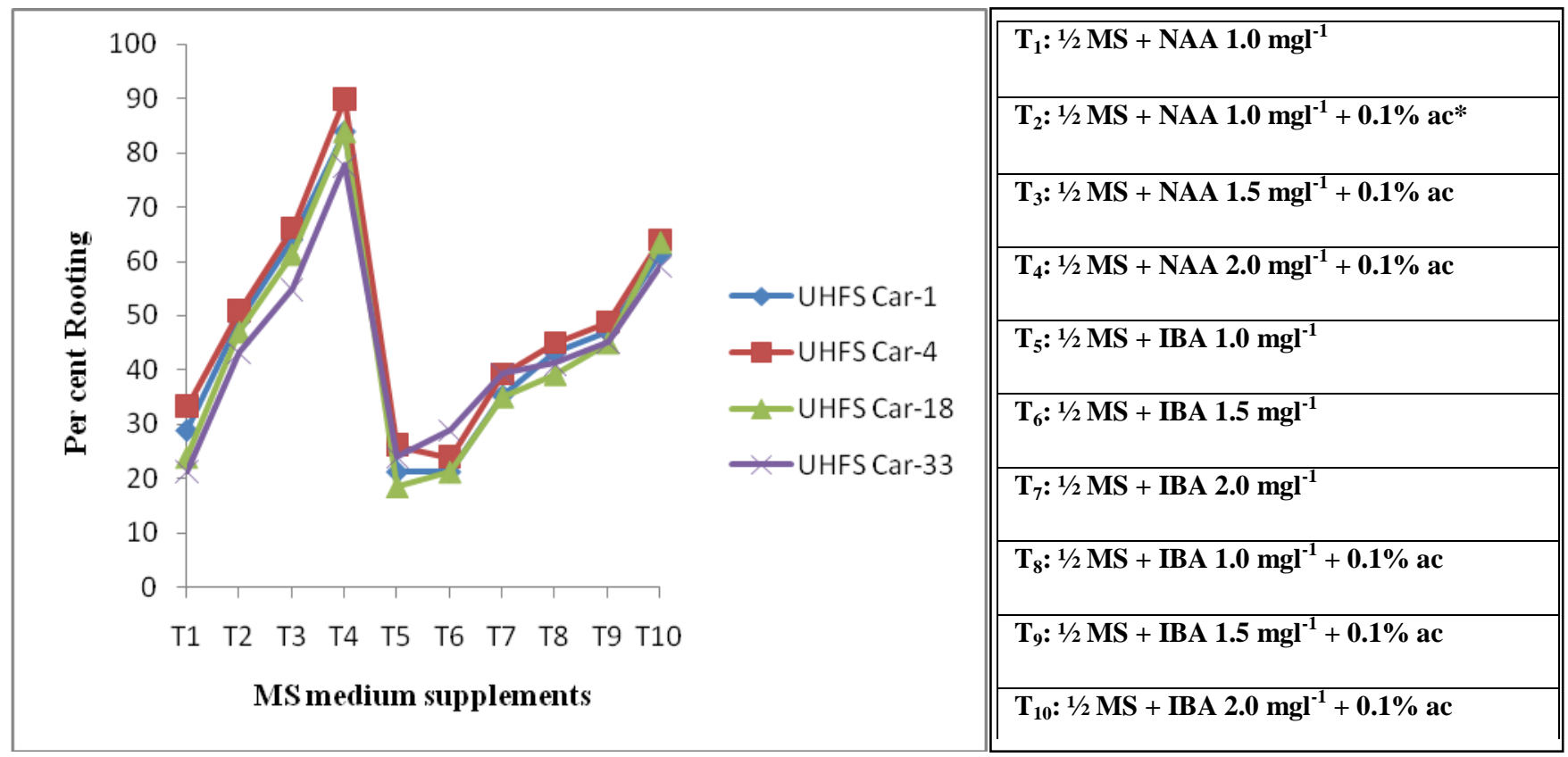

Fig.2 Effect of different hardening media on per cent survival of in vitro rooted plantlets of carnation

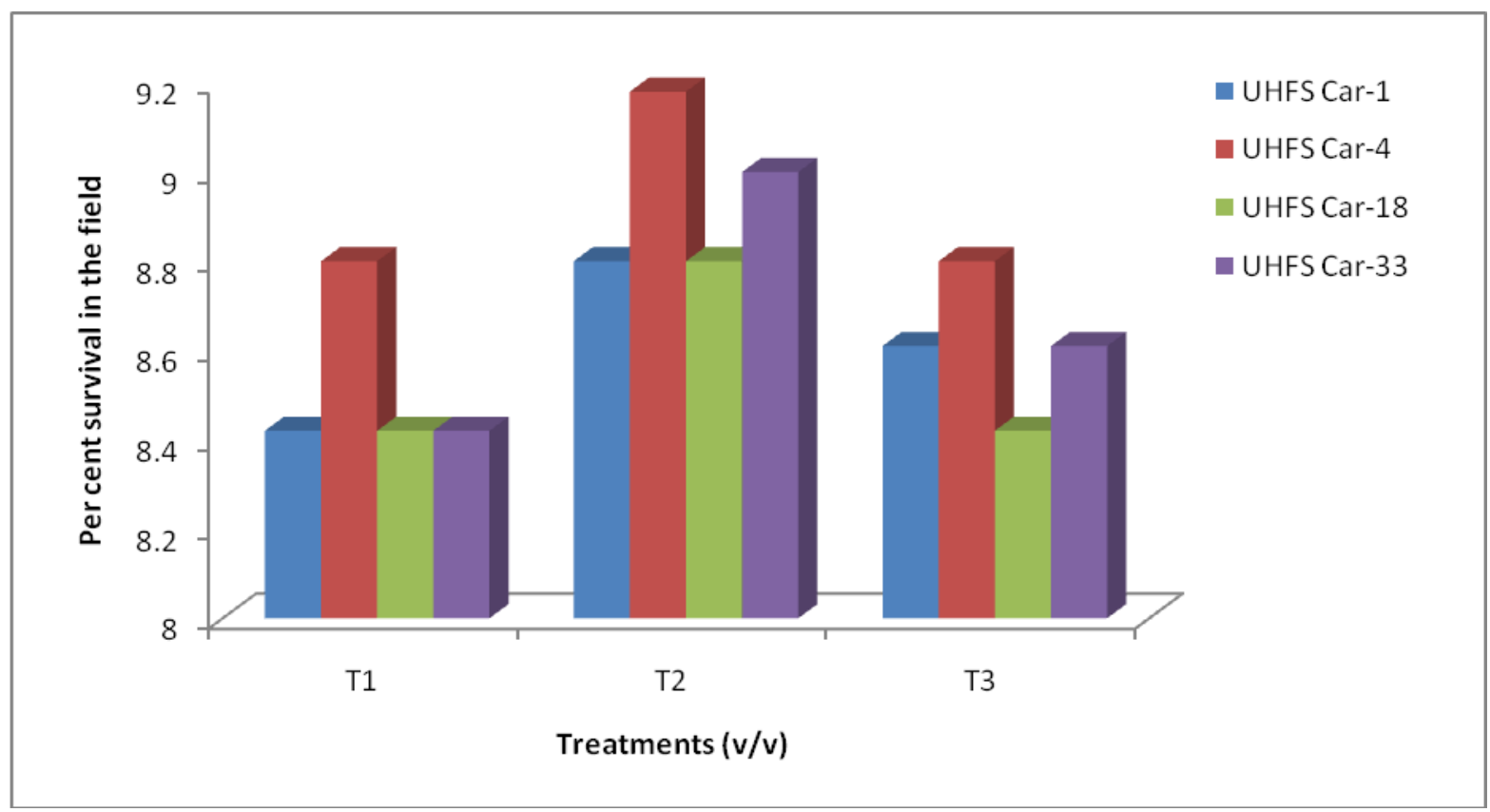

The difference among mutants with respect to length of shoots in multiplication medium could be attributed to the genotypic differences among them. Higher shoot length was observed in 'UHFS Car-4' than 'UHFS Car-33', 'UHFS Car-18' and 'UHFS Car-1'. Maximum length of shoots was observed when the nodal segments raised shoots of 
mutant 'UHFS Car-4' were cultured when MS medium was supplemented with $2.0 \mathrm{mgl}^{-1}$ $\mathrm{BA}+0.1 \mathrm{mgl}^{-1} \mathrm{NAA}+1.0 \mathrm{mgl}^{-1} \mathrm{GA}_{3}$. The results are supported by the work carried out by Mujib et al., (1993) who used shoot tips and node cuttings as explants for in vitro regeneration of shoots in carnation cv. 'William Sim' and reported better shoot length from cultures raised from node cuttings.

The role of cytokinins in combination with low concentration of auxin in increasing length of shoot has been observed in the present study. Maitra et al., (2011) carried out a study in which explants cultured on MS medium supplemented with $1.0 \mathrm{mgl}^{-1}$ NAA and $2.5 \mathrm{mgl}^{-1}$ kinetin produced longest shoots $(6.60 \mathrm{~cm})$. Similarly Mujib and Pal, 1995 reported that carnation shoot length was increased in vitro by addition of NAA in a medium containing BA.

In our studies, addition of $\mathrm{GA}_{3}$ in MS medium containing BA and NAA has a profuse effect on shoot elongation with maximum shoot length found with $2.0 \mathrm{mgl}^{-1} \mathrm{BA}+0.1 \mathrm{mgl}^{-1}$ $\mathrm{NAA}+1.0 \mathrm{mgl}^{-1} \mathrm{GA}_{3}$. The effect of $\mathrm{GA}_{3}$ on shoot elongation has been clearly reported by Can and Koc (1992) in carnation.

Genotypic variation amongst mutants is also evident from the data wrt per cent rooting of in vitro regenerated shoots as presented in Figure 1. Highest per cent rooting $(53.66 \%)$ was recorded in mutant 'UHFS Car-4' whereas, rooting percentage was minimum in shoots of 'UHFS Car-33' (46.66\%). Among different media supplements used, MS (half strength) medium supplemented with $2.0 \mathrm{mgl}^{-}$ ${ }^{1} \mathrm{NAA}+0.1 \%$ activated charcoal $\left(\mathrm{T}_{4}\right)$ proved to be the best medium and effected maximum rooting $(96.66 \%)$ in carnation mutants. In contrast, minimum rooting $(15.0 \%)$ of in vitro raised shoots was noted in MS (half strength) medium containing $1.0 \mathrm{mgl}^{-1} \mathrm{IBA}$
$\left(\mathrm{T}_{5}\right)$. In general, NAA was found better for in vitro rooting of carnation shoots. Further, a considerable increase in rooting percentage was observed with increasing NAA concentration in the medium upto $2.0 \mathrm{mgl}^{-1}$, irrespective of mutants. Although all the mutants rooted successfully, yet highest per cent rooting was observed in 'UHFS Car-4'. The differential behaviour of carnation cvs with respect to per cent rooting is genotype dependent as supported by Kallak et al., (1997) and Salehi (2005).

Further, NAA was found to be more efficient in inducing rooting as compared to IBA. These results are in close conformity with the reports of Kadu (2013) who obtained 96\% rooting in carnation in vitro raised shoots when cultured on MS medium containing 2.0 $\mathrm{mgl}^{-1}$ NAA and $0.2 \%$ activated charcoal. Profuse rooting was observed in carnation cvs. 'White Sim', 'Exquisite' and 'Scania' on MS medium supplemented with different concentrations of NAA i.e. $1.0 \mathrm{mgl}^{-1}, 1.5 \mathrm{mgl}^{-}$ ${ }^{1}$ and $2.0 \mathrm{mgl}^{-1}$ (Yadav et al., 2012). Ali et al., (2008) and Jaggi (2013) also confirmed that NAA is the most effective rooting hormone for in vitro rooting of carnations.

The data presented in Figure 2 depicts that different hardening media significantly affected hardening of in vitro regenerated plantlets. Highest survival $(79.16 \%)$ of plants under field conditions was, however recorded when in vitro raised plants of carnation were hardened in medium containing sand + cocopeat + vermicompost $(1: 1: 1, \quad \mathrm{v} / \mathrm{v})$. Mutants also showed significant difference from each other with respect to per cent survival in field. Maximum survival was noted for 'UHFS Car-4' (78.88\%). In contrast, least survival recorded for 'UHFS Car-18' (72.22\%). Similar results were, however recorded in 'UHFS Car-1' (73.33\%) and 'UHFS Car-33' (74.44\%). 
Optimum porosity, aeration and moisture holding capacity of this medium provided excellent conditions for establishment in the field. Dharma (2003) and Dogra (2007) also obtained successful results when carnation plantlets were hardened on medium containing cocopeat.

\section{References}

Ahloowalia BS, Prakash $\mathrm{J}$ and Savangikar VA. 2002. Low cost options for tissue culture technology in developing countries. In: Proceedings of $a$ Technical Meeting organized by the Joint FAO/IAEA Division of Nuclear Techniques in Food and Agriculture, held at Vienna, 26-30 August 2002. IAEA, Austria. pp. 3-10.

Ali A, Afrasiab H, Naz S, Rauf M and Iqhbal J. 2008. An efficient protocol for in vitro propagation of carnation (Dianthus caryophyllus L.). Pakistan Journal of Botany 40:111-21.

Can C and Koc NK. 1992. Investigation on in vitro micropropagation of carnation (Dianthus sp.) through meristem culture techniques. Dpga Turk Tarm-veOrmanclk-Dergisi 16:641-48.

Choudhary ML. 1991. Vegetative propagation of carnation in vitro through multiple shoot development. Indian Journal of Horticulture 48: 177-81.

Dharma S. 2003. Studies on Factors Influencing the Production of Hardened Glaucous Carnation Plantlets. M.Sc. Thesis. Department of Floriculture and Landscape Architecture, Dr Y S Parmar University of Horticulture and Forestry, Solan. 120p.

Dodds JH and Roberts LW. 1982. Experiments in Plant Tissue Culture. Cambridge University Press, London. $178 \mathrm{p}$.

Dogra S. 2007. In vitro Mutagenesis in Carnation (Dianthus caryophyllus L.) for Induction of Resistance to Fusarium Oxysporum f. sp. Dianthi. Ph.D Thesis. Department of Floriculture and Landscape Architecture, Dr Y S Parmar University of Horticulture and Forestry, Solan.177p.

Gautam B. 2015. Studies on In vitro Propagation of Carnation (Dianthus caryophyllus L.). M.Sc. Thesis. Department of Floriculture and Landscape Architecture, Dr YS Parmar University of Horticultureand Forestry, Solan.75p.

Ghosh S and Mohan Ram YH. 1986. Multiplication of spray carnation by axillary bud culture. Current Science 55:966-71.

Hassan AKM Sayeed, Munshi JL, Sultana R, Jahan MAA and Khatun R. 2011. High frequency in vitro regeneration of Dianthus caryophyllus L., a herbaceous perennial ornamental plant. Bangladesh Journal of Scientific and Industrial Research 46:495-98.

Hempel M. 1979. Studies on in vitro multiplication of carnations $\mathrm{I}$. The influence of some kinetins on the differentiation of shoot apices. Acta Horticulturae 91:317-21.

Iantcheva A, Vlahova M, Atanassova B and Atanassov A. 2005. Plant regeneration via direct organogenesis and somatic embryogenesis of two Bulgarian spray carnation cultivars. Biotechnology \& Biotechnological Equipment 19:15-19.

Jaggi D. 2013. A Micropropagation System for Carnation (Dianthus caryophyllus L.)-an Important Ornamental Plant. M.Sc. Thesis. Department of Biotechnology and Environmental Sciences, Thapar University, Patiala.78p.

Kadu AR. 2013. In vitro micropropagation of gerbera using axillary bud. Asian Journal of Bio Science 8:15-18.

Kallak H, Reidla M, Hilpus I and Virumae K. 
1997. Effects of genotype, explant source and growth regulators on organogenesis in carnation callus. Plant Cell, Tissue and OrganicCulture 51:125-27.

Kansagra M, Pawar V, Bhatt K, Chudasama $\mathrm{R}$ and Thakur V. 2008. Role of cationic and anionic peroxidase in browning of multiple shoots of carnation (Dianthus caryophyllus L.) in vitro. Indian Journal of Plant Physiology 13:317-19.

Kharrazi M, Nemati H, Tehranifar A, Bagheri A and Sharifi A. 2011. In vitro culture of carnation (Dianthus caryophyllus L.) focusing on the problem of vitrification. Journal of Biological and Environment Sciences 5:1-6.

Maitra S, Roychowdhury N, Ghosh PD and Satya P. 2011. Effect of kinetin and NAA on regeneration of Carnation (Dianthus caryophyllus L.) from shoottip explants. International Journal of Bio-resource and Stress Management 2:287-92.

Markovic M, Popovic M and Vilotic D. 2013. Micropropagation of Dianthus deltoides L. through shoot tip and nodal cuttings culture. Archives of Biological Sciences 65:17-22.

Misra S, Pragya and Misra RL. 2006. Carnation. In: Advances in Ornamental Horticulture (Bhattacharjee SK ed). Pointer Publisher Jaipur, India. pp.6680.

Mujib A and Pal AK. 1995. Inter varietal variation in response to in vitro cloning of carnation. Crop Research-Hisar 32:127-28.

Mujib A, Pal AK and Jana BK. 1993. Effect of growth regulators on plantlet regeneration of carnation from shoot tip and node cuttings in vitro. Maharashtra Journal of Horticulture 7:96-98.

Murashige T and Skoog F. 1962. A revised medium for rapid growth and bioassay with tobacco tissue cultures. Plant
Physiology 15:472-97.

Pennazio S. 1975. Effects of adenine and kinetin on development of carnation meristem tips cultured in vitro. Journal of Horticultural Science 50:161-64

Pareek A, Kantia A and Kothari SL. 2004. In vitro cloning of ornamental species of Dianthus. Indian Journal of Biotechnology 3:263-66.

Qaoud HA. 2013. Adventitious shoot formation and plant regeneration from leaf explants of carnation (Dianthus caryophyllus L.). African Journal of Biotechnology 12:3244-49.

Roest S and Bokelmann GS. 1981. Vegetative propagation of carnation in vitro through multiple shoot development. Scientia Horticulturae 14:357-66.

Salehi H. 2005. Can a general shoot proliferation and rooting medium be used for anumberof carnation cultivars? African Journal of Biotechnology 5:2530.

Sangwan RS, Detrez C and Sangwan NBS. 1987. In vitro culture of shoot tip meristems in some higher plants. Acta Horticulturae 212:661-66.

Sharma, Puja, Dhiman, SR, Gupta, YC, Sharma, Priyanka and Gautam, Bharati. 2016. Effects of genotype, explants type and growth regulators on organogenesis in carnation. International Journal of Bio-resource and Stress Management 7(5):1152-1155

Sheoran OP, Tonk DS, Kauhik LS, Hasija RS and Pannu RS. 1998. Statistical software package for agricultural research workers. In:Recent Advances in Information Theory, Statics and Computer Application (Hooda DS and Hasija RS eds). Department of mathematics statistics, CCS HAU, Hisar. pp.139-43.

Skoog F and Miller C. 1957. Chemical regulation of growth and organ formation in plant tissue cultured in 
vitro. Symposium on Social and Experimental Biology 11:118-31.

Varshney A, Anis M and Aref IM. 2013. Potential role of cytokinin- auxin synergism. In vitro Cellular and Developmental Biology- Plant 49:16674.

Yadav MK, Singh RK, Yadav D, Tripathi
MK, Rana B, Sirohi A, Kumar R and Garg GK.2012. Effect of ABA and $\mathrm{GA}_{3}$ on hyperhydricity and assessment of in vitro and ex vitro rooting pattern for suitability of acclimatization in carnation. Progressive Agriculture 12:11-18.

\section{How to cite this article:}

Rishu Doad, Puja Sharma, S.R. Dhiman and Priyanka Sharma. 2019. Development of in vitro Propagation Protocol for Newly Developed Mutants of Carnation (Dianthus caryophyllus L.). Int.J.Curr.Microbiol.App.Sci. 8(04): 183-195. doi: https://doi.org/10.20546/ijcmas.2019.804.019 